Sains Malaysiana 50(11)(2021): 3251-3261

http://doi.org/10.17576/jsm-2021-5011-09

\title{
Kinetic Modeling of Essential Oil Hydro-Distillation from Peels of Pomelo (Citrus grandis L.) Fruit Grown in Southern Vietnam
}

(Pemodelan Kinetik Penyulingan Hidro Minyak Pati daripada Kulit Buah Pomelo (Citrus grandis L.) Ditanam di Vietnam Selatan)

Tan Phat Dao, Huynh Xuan Phong, Mai Huynh Cang, Long Giang Bach* \& Nguyen Van Muoi

\begin{abstract}
Thorough understanding of kinetics plays a key role in improving existing industrial processes. In this study, we attempted to model the kinetics of the hydro-distillation process that produces essential oil from peels of pomelo (Citrus grandis L.) fruit, which is a product with high economic value and a wide range of applications. We first determined the optimal water-to-material ratio for attaining maximal oil yield. Then, further experimental attempts were carried out at different distillation rates to generate experimental data to fit three kinetic models, namely first-order kinetics model, instantaneous washing, followed by diffusion model and simultaneous washing and diffusion model. Overall, the three models have well described the experimental kinetic data on hydro-distillation $\left(R^{2}>90 \%\right)$. Of which, the simultaneous washing and diffusion model attaining the $R^{2}$ of $99.97 \%$ was chosen as the most suitable to describe the kinetics of the extraction process. Estimated parameters also shown that the washing stage occurs more rapidly than the later, diffusion stage. GC-MS results showed that the obtained oil sample was characterized by the dominance of the D-Limonene compound (97.873\%).
\end{abstract}

Keywords: Citrus grandis L.; essential oils; hydrodistillation; kinetics; instantaneous washing followed by diffusion model; simultaneous washing and diffusion model

ABSTRAK

Pemahaman menyeluruh tentang kinetik memainkan peranan penting dalam menambah baik proses perindustrian sedia ada. Dalam kajian ini, kami cuba memodelkan kinetik proses penyulingan hidro yang menghasilkan minyak pati daripada kulit buah pomelo (Citrus grandis L.), yang merupakan produk dengan nilai ekonomi yang tinggi dan pengaplikasian yang pelbagai. Kami mula-mula menentukan nisbah air-ke-bahan yang optimum untuk mencapai hasil minyak maksimum. Kemudian, percubaan uji kaji selanjutnya dijalankan pada kadar penyulingan yang berbeza untuk menjana data uji kaji agar sesuai dengan tiga model kinetik, iaitu model kinetik tertib pertama, cucian segera, diikuti model resapan dan model cucian dan resapan serentak. Secara keseluruhannya, ketiga-tiga model telah menerangkan dengan baik data kinetik uji kaji pada penyulingan hidro (R2>90\%). Antaranya, model cucian dan resapan serentak yang mencapai R2 sebanyak 99.97\% telah dipilih sebagai yang paling sesuai untuk menggambarkan kinetik proses pengekstrakan. Parameter anggaran juga menunjukkan bahawa peringkat pencucian berlaku lebih cepat daripada peringkat penyebaran. Keputusan GC-MS mendedahkan bahawa sampel minyak yang diperoleh dicirikan oleh penguasaan sebatian D-Limonene (97.873\%).

Kata kunci: Citrus grandis L.; cucian segera diikuti dengan model resapan; kinetik; minyak pati; model cucian dan resapan serentak; penyulingan hidro

\section{INTRODUCTION}

The ecological and geographic conditions of the tropical and subtropical regions of South Asia have led to the widespread development of species in the citrus groups (of the Citrus rutaceae family). Vietnam, due to its favorable tropical monsoon climate, has recently became a leading grower and a major exporter of pomelo (Citrus grandis (L.) Osbeck), which is a fruit species with high economic value (Lan-Phi \& Vy 2015; Puglisi et al. 2017; Van-Hoang 2014). According to General Statistics Office 
of Vietnam (2019) nationwide, there are around 27,900 hectares reserved for Citrus production spanning across the Mekong Delta region and some provinces in Middle and Northern Vietnam, yielding approximately 433,900 tons of pomelo in 2019. While the flesh of pomelo has been known to abundantly contain Vitamin C (Morton \& Dowling 1987), the pomelo by-products, such as leaves and peels, provide a wide range of applications in the aromatherapy, pharmaceutical and food industry.

One common product that is derived from the pomelo by-products is pomelo essential oils. The pomelo essential oils have been shown to consist of complex mixtures with many pure monoterpene, oxidized monoterpene, and sesquiterpene hydrocarbon. Specifically, components found in the essential oils may include $\alpha$-pinene, $\beta$-myrcene, sabinene, and limonene (Gonzalez-Mas et al. 2019). Among them, sabinene, limonene and $\alpha$-pinene are constituents that have been found to possess antioxidant activities by DPPH scavenging assays. Limonene, which is a major compound in pomelo essential oil composition, is also a common ingredient in manufacture of dietary supplements, cosmetics, and functional materials. In addition, it has been found that the co-existence of certain components, including $\alpha$-pinene and myrcene confers antimicrobial activities to pomelo essential oils (Lan-Phi \& Vy 2015).

Essential oils are often obtained, in both laboratory and industrial scale, using hydro-distillation (HD) extraction technique, which is renowned for its low investment costs and convenience (Dao et al. 2019; Quyen et al. 2019; Tran et al. 2019). The kinetics of conventional hydro-distillation is extensively studied, and it has been shown that the essential oil change over time during the hydro-distillation process could be best described by kinetic that incorporates both washing and diffusion stage. Milojevic et al. (2008) studied the kinetics of juniper essential oil distillation with two-parameter model of unsteady-state diffusion and proposed an appropriate linear regression model, suggesting the existence of two stages in hydro-distillation: fast distillation (washing phase) and slow distillation or diffusion. The model was tested and evaluated by the dependence of essential oil depletion $\left(\ln \left[\left(\mathrm{q}_{\mathrm{o}}-\mathrm{q}\right) / \mathrm{q}_{\mathrm{o}}\right]\right)$ on time, indicating the suitability of the linear form of the curves with the experimental data (coefficient $\mathrm{R}^{2}>97 \%$ ). A similar model was presented in another study (Stanisavljević et al. 2010) which explored the extraction kinetics of Cherry Laurel leaves, resulting the $\mathrm{R}^{2}$ of higher than 0.95 and the slow distillation coefficient of $0.0384 \mathrm{~min}^{-1}$. Similar models and results were obtained in another study involving kinetics of sandalwood essential oil (Jutarut et al. 2011).
To the best of our knowledge, kinetics of essential oil recovery processes from pomelo materials have not been adequately modeled. There is one particular study that dealt with kinetics of oil recovery from various plant materials including orange, pomelo and lemongrass (Nguyen et al. 2018). However, the applied technique was steam distillation, which requires higher capital and operational costs, and the processes were modelled at a fixed distillation rate. Given the potential of pomelo by-products for production of essential oils with useful bioactive compounds, in this study, we modeled the hydro-distillation kinetics of essential oils from peels of 'Long Co Co' pomelo, which is a pomelo variety widely grown in the Southern Vietnam. Three kinetics, including simultaneous washing and diffusion model, instantaneous washing followed by diffusion model and first-order kinetics model, were selected for estimation at different hydro-distillation rates. In addition, the obtained essential oil sample was then determined for volatile composition using GC-MS technique. The results are expected to contribute to further refinements of existing large-scale production models to improve economic efficiency.

\section{MATERIALS AND METHODS}

\section{PLANT MATERIAL AND CHEMICALS}

In this study, Pomelo (Citrus grandis) fruits of Long Co Co variety were collected from Tien Giang province (latitude $10^{\circ} 24^{\prime} 21^{\prime \prime} \mathrm{N}$ and longitude $105^{\circ} 56^{\prime} 1^{\prime \prime} \mathrm{E}$ ), Vietnam. Pomelo fruits were manually peeled. The peel yield was $10-20 \% \mathrm{w} / \mathrm{w}$ with respect to the weight of the whole fruit. Fresh peels were then used in hydrodistillation. All other chemicals and solvents used were of analytical grade.

\section{ESSENTIAL OIL ISOLATION}

Firstly, $100 \mathrm{~g}$ of pureed plant materials were placed in a $1 \mathrm{~L}$ flask and then a pre-determined amount of RO water was added. The flask was set up with hydro-distillation using a modified Clevenger device. The maximum distillation duration was $120 \mathrm{~min}$. This period was found to be appropriate for recovering essential oils from the Citrus species (Tan et al. 2020, 2019; Quyen et al. 2019). After distillation, essential oils were separated from the water by $\mathrm{Na}_{2} \mathrm{SO}_{4}$ and stored in a sealed vial at $4{ }^{\circ} \mathrm{C}$ before being used for analysis. Each experiment was carried out in triplicate and mean values were reported as results. Yield of pomelo oil was found by the following equation:

$$
Y=\frac{V \times 100}{W}
$$


where $Y$ is the essential oil yield from pomelo peels ( $\%$, $\mathrm{v} / \mathrm{w}, \mathrm{mL} / 100 \mathrm{~g}$ materials); $V$ is the volume of extracted essential oil obtained $(\mathrm{mL})$; and $W$ is the amount of pomelo peels $(\mathrm{g})$.

\section{CALCULATION OF KINETIC PARAMETERS}

The mechanism explaining the hydrodistillation of essential oils from the material to the media has been shown to consist of two stages including washing and diffusion (Milojevic et al. 2013). Washing refers to the stage in which essential oils are washed from the internal of the materials to the surrounding media and is characterized by the rapid release of essential oils. Meanwhile, diffusion is the process in which essential oils are slowly diffused from the plant tissues outward, then washed away by the steam (Milojević et al. 2008). Based on this proposition and the order at which these stages occur, three main models have been devised in the literature to describe the hydro-distillation process: simultaneous washing and diffusing of essential oils (2); physical model with instantaneous washing followed by diffusion (3) or diffusion without washing (i.e. first order kinetics, (4)). Mathematical forms of the three kinetic models that were adopted in this study are described as follows.

TABLE 1. Hydro-distillation kinetic models of Citrus grandis L. peels oil

\begin{tabular}{lll}
\hline \multicolumn{1}{c}{ Kinetic model } & Kinetic equation & Parameters \\
\hline $\begin{array}{l}\text { Simultaneous washing and diffusion } \\
\text { model }\end{array}$ & $\frac{q}{q_{\infty}}=1-f e^{-k_{1} t}-(1-f) e^{-k_{2} t}(2)$ & $\mathrm{k}_{1}, \mathrm{k}_{2}$, and $\mathrm{f}$ \\
$\begin{array}{l}\text { Instantaneous washing followed by diffu- } \\
\text { sion model }\end{array}$ & $\frac{\mathrm{q}}{\mathrm{q}_{\infty}}=1-(1-\mathrm{f}) \mathrm{e}^{-\mathrm{k}_{2} \mathrm{t}}(3)$ & $\mathrm{k}_{2}$ and $\mathrm{f}$ \\
First-order kinetics model & $\frac{\mathrm{q}}{\mathrm{q}_{\infty}}=1-\mathrm{e}^{-\mathrm{k}_{2} \mathrm{t}}(4)$ & $\mathrm{k}_{2}$ \\
\hline
\end{tabular}

where $q$ is the amount of essential oil extracted after time $t$ and $q_{\infty}$ is the initial essential oil in the materials. The parameters of (2) - (4) are calculated by fitting experimental data including $\mathrm{q}$ ratio and time values. The coefficient of determination $\mathrm{R}^{2}$ was used the assess model suitability.

\section{DETERMINATION OF ESSENTIAL OIL COMPOSITION}

Gas Chromatography-Mass Spectrometry (GC-MS) technique was employed to determine the composition of the obtained essential oils. GC Agilent $6890 \mathrm{~N}$ instrument was used with MS 5973 inert with HP5-MS column. The analytical sample was prepared by adding $25 \mu \mathrm{L}$ sample of essential oil in $1.0 \mathrm{~mL}$-hexane. The pressure of the column was set to $9.3 \mathrm{psi}$. Helium was used as the carrier gas. The flow rate was set at $1.0 \mathrm{~mL} / \mathrm{min}$. The split ratio was $1: 100$. The injection volume and temperature were $1.0 \mu \mathrm{L}$ and $250{ }^{\circ} \mathrm{C}$, respectively. The thermal profile is initiated at $50{ }^{\circ} \mathrm{C}$ for $2 \mathrm{~min}$, followed by an elevation at 2 ${ }^{\circ} \mathrm{C} / \mathrm{min}$ to $80^{\circ} \mathrm{C}$, then an elevation at $5^{\circ} \mathrm{C} / \mathrm{min}$ to $150{ }^{\circ} \mathrm{C}$, then an elevation at $10^{\circ} \mathrm{C} / \mathrm{min}$ to $200^{\circ} \mathrm{C}$, then finally an elevation at $20^{\circ} \mathrm{C} / \mathrm{min}$ to $300{ }^{\circ} \mathrm{C}$, which was maintained for $5 \mathrm{~min}$.

\section{RESULTS AND DISCUSSION}

We first conducted a series of single-factor optimization taking into account different extraction parameters to determine the optimal conditions that gave maximal oil yield.

\section{EFFECT OF EXTRACTION CONDITIONS}

Among the parameters affecting the HD process, water to materials ratio, which is the amount of water per amount of pomelo peels, was considered one of the main influencing factors. Based on previous studies on the essential oils of fruit peels such as orange Tan et al. (2019), calamondin (Quyen et al. 2019), and lemon fruit (Thien et al. 2019a), we selected the ratio of $3: 1 \mathrm{~mL} / \mathrm{g}$ as the standard ratio around which further experiments in this study were based. The ratios were selected in a way that neither burning or overflowing would occur. Multiple experiments were conducted at different ratios including $2: 1,3: 1,4: 1$, and $5: 1 \mathrm{~mL} / \mathrm{g}$ and for various distillation durations ranging from 10 to $120 \mathrm{~min}$. Other condition such as $2.5 \mathrm{~mL} / \mathrm{min}$ of distillation rate was kept constant in experiments of this investigation. 
As shown in the Figure 1, distillation yields reached the lowest at the $2: 1$ ratio and the maximum yield of the process was obtained at the ratio of $3: 1 \mathrm{~mL} / \mathrm{g}$. After $120 \mathrm{~min}$, when the ratio increases from $2: 1$ to $3: 1 \mathrm{~mL} / \mathrm{g}$, obtained yield was improved from 2.9 to peak yield of $3 \%$. In addition, yields obtained at 4:1 and 5:1 ratio seemed to be lower than peak yields. This relationship could be explained by the greater diffusion of oil into water and improved absorption of water vapor into essential oil-bearing epidermis with sufficient water submersion, breaking down oil sacs and carrying oil via evaporation. On the other hand, insufficient water might not melt the plant adhesives and in turn can cause material adhesion, obstructing the escape of essential oils. Another study also posited that excessive water may cause dissolution and hydrolytic transformation of volatiles, hindering the extraction efficiency (Dhobi et al. 2009). It is worth noting that the use of excessive water may lead to longer time required to attain optimal oil yield, which is economically unfavorable. Clearly, at the 3:1 ratio, peak oil yield was achieved after $70 \mathrm{~min}$ whereas at the 5:1 ratio, the highest yield was attained after $100 \mathrm{~min}$. Due to those considerations, the optimum ratio of solventmaterial for subsequent studies is selected as $3: 1 \mathrm{~mL} / \mathrm{g}$.

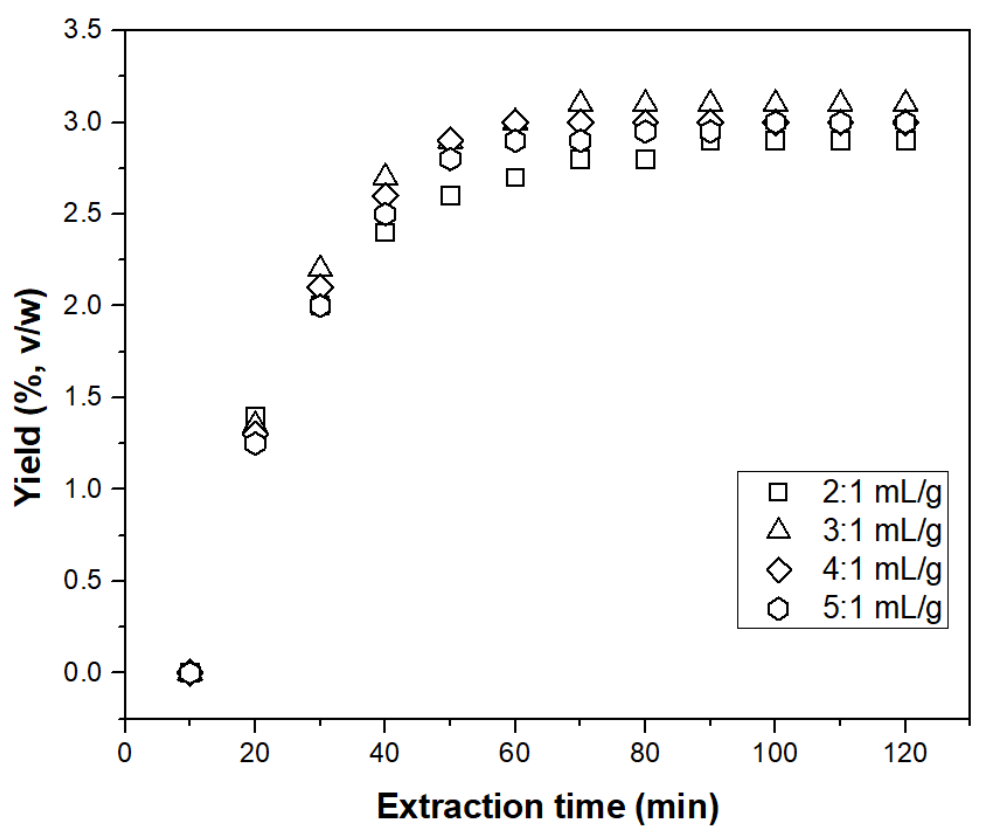

FIGURE 1. The amount of extraction pomelo oil different ratio of water to material

Another important parameter affecting hydrodistillation is distillation rate, which is the amount of distillate exiting the system in a given time period and could be controlled by adjusting the heating of the system. At the heating power of 170, 204, $238 \mathrm{~W}$, the distillation rate was $2.1,2.5$, and $3.7 \mathrm{~mL} / \mathrm{min}$, respectively.

Figure 2 illustrates the oil yields obtained at different extraction durations and distillation rates. It was shown that rising the distillation rate from 2.1 to 2.5 $\mathrm{mL} / \mathrm{min}$ improved the oil yield. The highest efficiency $(3.1 \%, v / w)$ is obtained when the distillation rate was set at $2.5 \mathrm{~mL} / \mathrm{min}$ and at extraction time of at least 70 min. Since higher power input leads to increased energy dissipated into the suspension, distillation capacity of the system was also enhanced. In addition, higher capacity also contributes to more thorough removal of oil existing on the material surface and promotes oil diffusion from plant cells to the surrounding media. However, extreme heat may cause thermally sensitive compounds to decompose, reducing the oil yield. Indeed, Figure 2 indicates that the yields obtained at the highest investigated distillation rate, $3.7 \mathrm{~mL} / \mathrm{min}$, were all lower than those obtained at $2.5 \mathrm{~mL} / \mathrm{min}$. On the other hand, at the lowest distillation rate $(2.1 \mathrm{~mL} / \mathrm{min})$, the yields were significantly lower than yields obtained at higher rates. This is explained by the insufficient energy dissipation required to free essential oils and the degradation of heat-resistant components when being exposed to heat in an extended period. In this investigation, the distillation rate of $2.5 \mathrm{~mL} /$ min was selected for subsequent studies. 


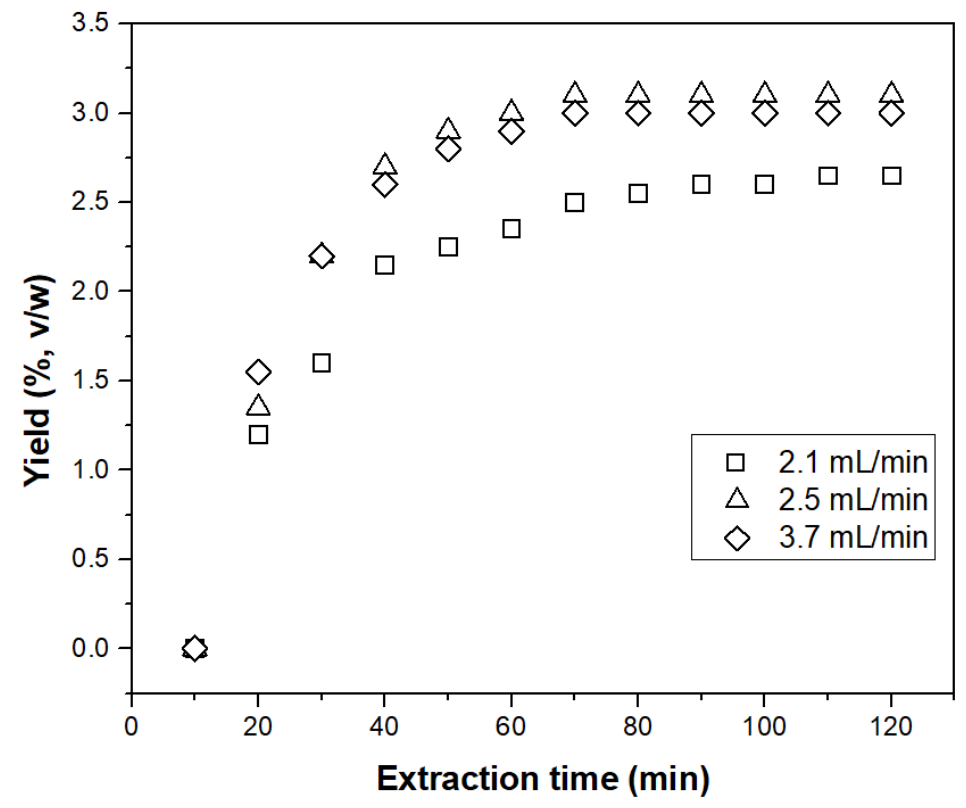

FIGURE 2. The amount of extracted pomelo oil at different ratio of hydro-distillation rates

Extraction time is also another factor that justifies economic feasibility of the process. From Figures 1 and 2, it was observed that peak yields obtained at their respective optimal conditions were attained after 70 min. This is in line with previous results suggesting that most Citrus essential oils are extracted after $60 \mathrm{~min}$ (Tan et al. 2020; Thien et al. 2019b), and in some cases, an extraction time of at least $70 \mathrm{~min}$ is required. Therefore, at optimal conditions (water-to-material ratio of $3: 1 \mathrm{~mL} / \mathrm{g}$ and distillation rate of $2.5 \mathrm{~mL} / \mathrm{min}$ ), $70 \mathrm{~min}$ was selected as optimal extraction time.

\section{KINETIC MODEL}

The yields of pomelo oil in different distillation rate settings $(2.1-3.7 \mathrm{~mL} / \mathrm{min})$ were fitted to three experimental kinetic models. Further analysis of the experimental kinetic curve of the hydro-distillation showed that the curve exhibited the typical solvent extraction curve consisting of two stages: the fast extraction (washing stage), during which essential oils resided in the external surface of the material are washed and the slow extraction stage (diffusion stage), during which essential oils are moved from the inside of the material to the outside media. The latter stage is characterized by a slow, gradual improvement in oil yield (Milojević et al. 2008). The curves that show the change of pomelo peel essential oil yield in the experiment were sigmoid or S-shaped with upward curvature towards the ordinate. This is consistent with previous experimental data (Figures $1 \& 2$ ) showing that the yield of the essential oil increased rapidly in the first phase (i.e. fast distillation phase) and slowed down until the oil output was almost constant (i.e. slow distillation phase).

According to Figures 3-5, for most power settings, three kinetic steps can be observed. Firstly, an almost linear increase in the first step of the hydro-distillation occurred, followed by a rapid increase in extraction yield at 20-70 min (second step) and a slow increase with a longer extraction time until the time reached unchanged after 90 min of extraction. More than $90 \%$ of the total recovered oil is extracted in the second stage. The adherence to the sigmoid curve was also observed in previous studies involving kinetics of distillation of rosemary (Mateus et al. 2006) and Artemisia judaica L. (Charchari \& Hamadi 2007) essential oils. Moreover, in another study (Kusuma \& Mahfud 2017), it was also reported that the essential oil isolation follows three different stages: the equilibrium phase, the intermediate transition phase and the diffusion phase. To be specific, the reduced diffusion rate was observed with prolonged duration due to insignificant amount of extractable substances that is caused by high content of solute in the third phase. 


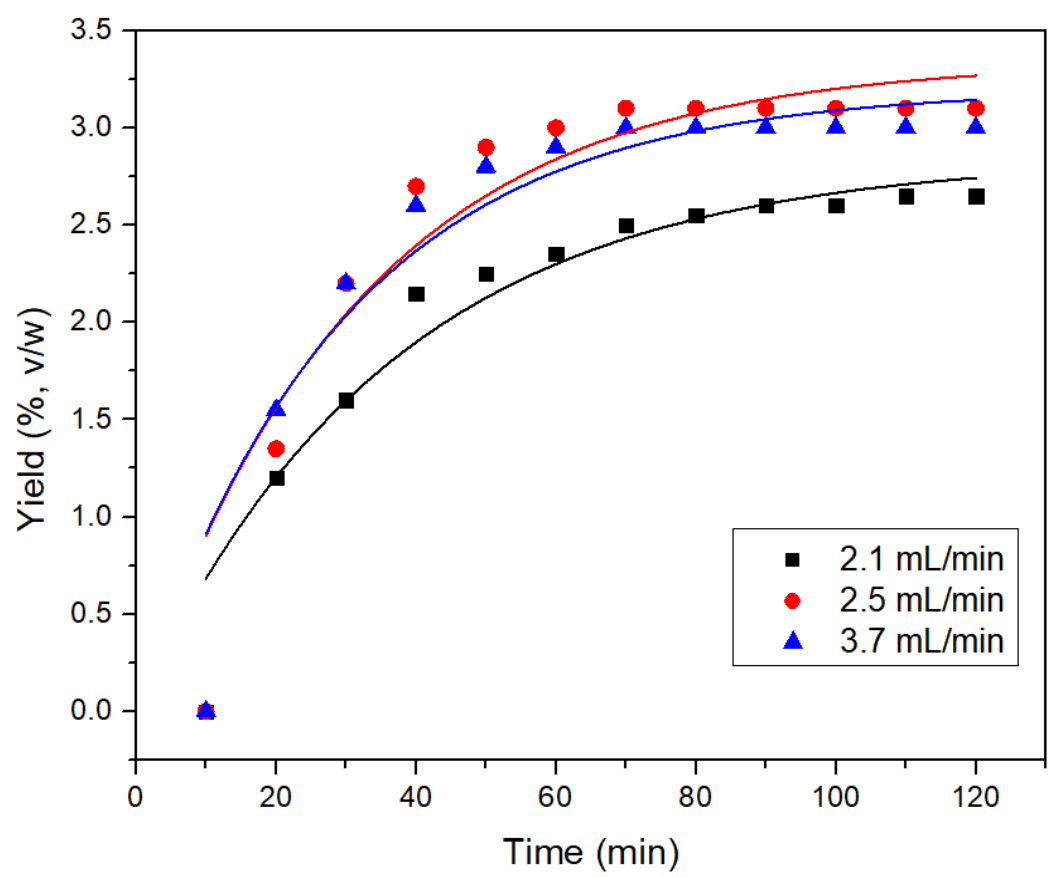

FIGURE 3. First-order kinetics model of pomelo peels oil at various hydro-distillation rate

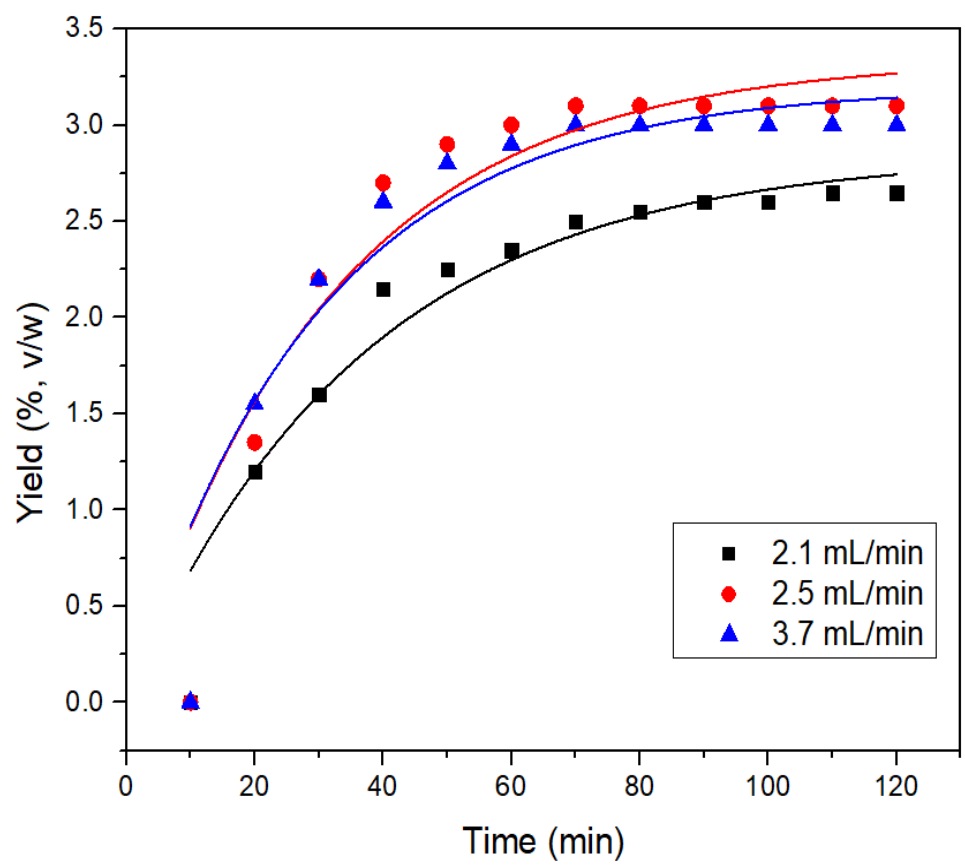

FIGURE 4. Instantaneous washing followed by diffusion kinetics model of pomelo peels oil at various hydro-distillation rate

Table 2 summarizes the $\mathrm{R}^{2}$ values and the estimated coefficients of three kinetic models. The results show that kinetic parameters such as $\mathrm{k}_{1}, \mathrm{k}_{2}$, $\mathrm{f}$ are generally increased with elevated power, except for the parameter in the third model. In the third model, both $\mathrm{k}_{1}$ and $\mathrm{f}$ values increased as the distillation rate increased from 


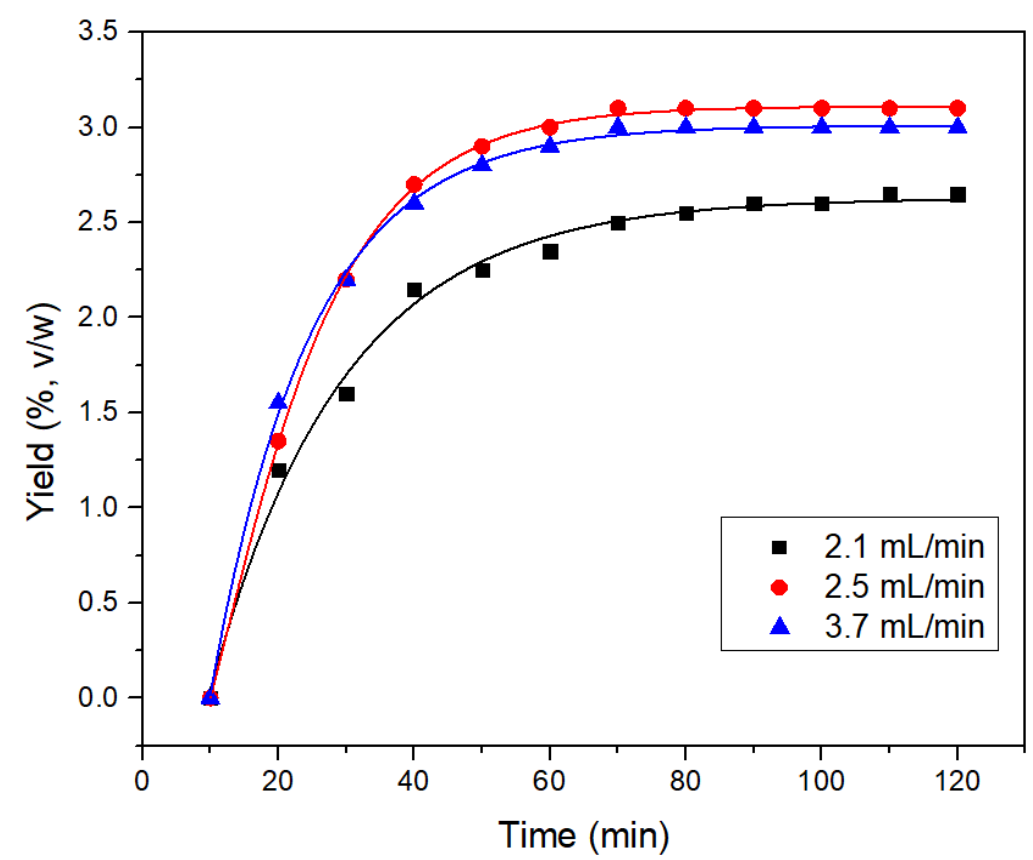

FIGURE 5. Simultaneous washing and diffusion kinetics model of pomelo peels oil at various hydro-distillation rate

2.1 to $2.5 \mathrm{~mL} / \mathrm{min}$. However, at distillation rate of $3.7 \mathrm{~mL} /$ min, these parameters were lower, except for the diffusion constant $\mathrm{k}_{2}$ which seemed to be irrelevant to distillation rate. These values were also found in the extraction of juniper essential oil (Marković et al. 2019), thyme, and Eucalypus cinerea (Milojevic et al. 2008). In addition, at the distillation rate of $2.5 \mathrm{~mL} / \mathrm{min}$, the highest $\mathrm{f}$-value of 2.90679 was obtained, which is greater than the rate constant, indicating that this at this distillation condition, more essential oils are available for washing by breaking more cell walls. In general, at higher power (i.e. $204 \mathrm{~W}$ and $238 \mathrm{~W}$ ), oil washing and diffusion from the pomelo peel occurred faster and more easily. However, when the power level was increased to $238 \mathrm{~W}$, the reverse effect of power on kinetic parameters and the yield reduction are evident. The results show that the low yield obtained may be the result of overheating that led to undesirable solvent extraction, thermal degradation of heat sensitive substances and instability of target compounds (Diaz Reinoso et al. 2017; Mohamad et al. 2012).

TABLE 2. Parameters of kinetic models for essential oil hydro-distillation of pomelo essential oil

\begin{tabular}{llllll}
\hline Model & $\begin{array}{l}\text { Distillation rate } \\
(\mathrm{mL} / \mathrm{min})\end{array}$ & $\begin{array}{l}\mathrm{k}_{1} \\
\left(\mathrm{~min}^{-1}\right)\end{array}$ & $\begin{array}{l}\mathrm{k}_{2} \\
\left(\mathrm{~min}^{-1}\right)\end{array}$ & $\mathrm{f}$ & $\mathrm{R}^{2}$ \\
\hline Pseudo-first & 2.1 & - & 0.0274 & - & 0.9107 \\
order & 2.5 & - & 0.0315 & - & 0.8771 \\
& 3.7 & - & 0.0337 & - & 0.8744 \\
\hline Instantaneous & 2.1 & - & 0.02743 & $5.5861 \mathrm{E}-12$ & 0.9008 \\
washing and & 2.5 & - & 0.03146 & $1.85028 \mathrm{E}-10$ & 0.8634 \\
diffusion & 3.7 & - & 0.03366 & $3.16316 \mathrm{E}-10$ & 0.8604 \\
\hline Simultaneous & 2.1 & & & & 0.9915 \\
washing and & 2.5 & 0.0512 & 2.8555 & 1.6419 & 0.9997 \\
diffusion & 3.7 & 0.0759 & 0.1659 & 2.90679 & 0.9988 \\
\hline
\end{tabular}


Model selection was justified by the goodness of fit (Haqqyana et al. 2020; Kusuma \& Mahfud 2017). The goodness of fit of the model is expressed through the coefficient of determination $\left(\mathrm{R}^{2}\right)$, which indicates better fit of the experimental data to the model if the coefficient is closer to 1 . The first-order and simultaneous washing and diffusion models seemed to be closely fit with the experimental data with relatively large $\mathrm{R}^{2}$ values (0.87-0.99). The good fit of the first-order model to the experimental data suggests that the actual hydro-distillation process may solely follow the first stage of washing and that the latter stage is non-existent (Haqqyana et al. 2020; Kitanović et al. 2008). Meanwhile, the good agreement of the simultaneous washing and diffusion model to the data is consistent with previous studies describing the extraction of natural substances from plant materials, which yielded fairly adequate $\mathrm{R}^{2}$ results (Milojević et al. 2008). Among the three models, the instantaneous washing followed by diffusion model has achieved the smallest $\mathrm{R}^{2}$ values $(0.86-0.90)$ at all power levels and can be considered unsuitable for hydrodistillation kinetics for pomelo peel. Based on $\mathrm{R}^{2}$ values and the suitability of the model for the actual process, the simultaneous washing and diffusion model was selected as the appropriate model to describe the mechanism of the hydro-distillation. The obtained simultaneous washing and diffusion model could be rewritten as follows.

$$
\frac{q}{q_{\infty}}=1-2.9068 e^{-0.0759 t}+1.9068 e^{-0.1659 t}
$$

The increase in distillation power also caused the kinetic parameters $\left(\mathrm{k}_{1}, \mathrm{k}_{2}\right)$ of the model to increase. During evaporation, water acts as a carrier of volatile substances before condensation takes place. Higher values of $\mathrm{k}$ also indicate enhanced ability of water to absorb the heat, which disrupts the plant matrix and in turn promotes the release of extractable content into the liquid phase. Since hydro-distillation rate is related to the extraction temperature, greater power levels lead to elevated temperature and in turn improved penetrability and solubility of the solvent. This also reduces solvent viscosity and surface tension, enhancing interaction of the solvent with plant matrix and resulting in higher yields and extraction rate.

\section{GC-MS ANALYSIS}

Determination of volatile components of the essential oil was carried out by referencing relative retention times

TABLE 3. Chemical composition pomelo peels oil

\begin{tabular}{|c|c|c|c|c|}
\hline R.T (min) & Compound & $\begin{array}{l}\text { Molecular } \\
\text { formula }\end{array}$ & Structure formula & Percent \\
\hline 7.24 & $\alpha$-Pinene & $\mathrm{C} 10 \mathrm{H} 16$ & & 0.456 \\
\hline 9.907 & $\beta$-Mycrene & $\mathrm{C} 10 \mathrm{H} 16$ & & 0.926 \\
\hline 11.904 & D-Limonene & $\mathrm{C} 10 \mathrm{H} 16$ & & 97.873 \\
\hline 17.948 & $\begin{array}{l}\text { Limonene } \\
\text { oxide-cis }\end{array}$ & $\mathrm{C} 10 \mathrm{H} 16 \mathrm{O}$ & & 0.21 \\
\hline 25.55 & Unknown & & & 0.263 \\
\hline 25.99 & Unknown & & & 0.272 \\
\hline
\end{tabular}


against those of authentic samples and mass spectra library. The essential oil sample was obtained at optimal conditions such as $3: 1 \mathrm{~mL} / \mathrm{g}$ of ratio, $2.5 \mathrm{~mL} / \mathrm{min}$ of hydrodistillation rate in $70 \mathrm{~min}$. The gas chromatographymass spectrometry results are presented in Table 3 and Figure 6. Six constituents were detected from the sample, of which, $99 \%$ of the compound has been identified and Limonene, $\alpha$-Pinene, $\beta$-Myrcene were the major compounds. Limonene, which is a monoterpene hydrocarbon, is the most abundant component with the content of $97.873 \%$. This is consistent with results of previous studies on pomelo essential oil, which reported that the content of limonene ranged from 62 to $95.4 \%$. The differences, albeit being not significant, could be explained by the genetic difference, used part of plant and the habitat in which species are grown (Karim et al. 2010). Limonene is a frequently used component in manufacture of functional foods, cosmetics, polymers, and adhesives. At a very high concentration, it was also found to possess insecticide activity and could be used as an anti-flea agent (Krishnan et al. 2017).

In general, the current composition that includes major compounds of D-Limonene, $\beta$-Mycrene, and $\alpha$-Pinene as major compounds well agrees with previous studies profiling pomelo essential oils (Burcu et al. 2011; Tan et al. 2020). The other important constituents were $\beta$-Myrcene $(0.926 \%)$ and $\alpha$ - Pinene $(0.456 \%)$ with a value retention time $9.907 \mathrm{~min}$ and $7.24 \mathrm{~min}$, respectively. These results are similar with the other literature data for Citrus genus (Chen et al. 2013; Minh Tu et al. 2002).

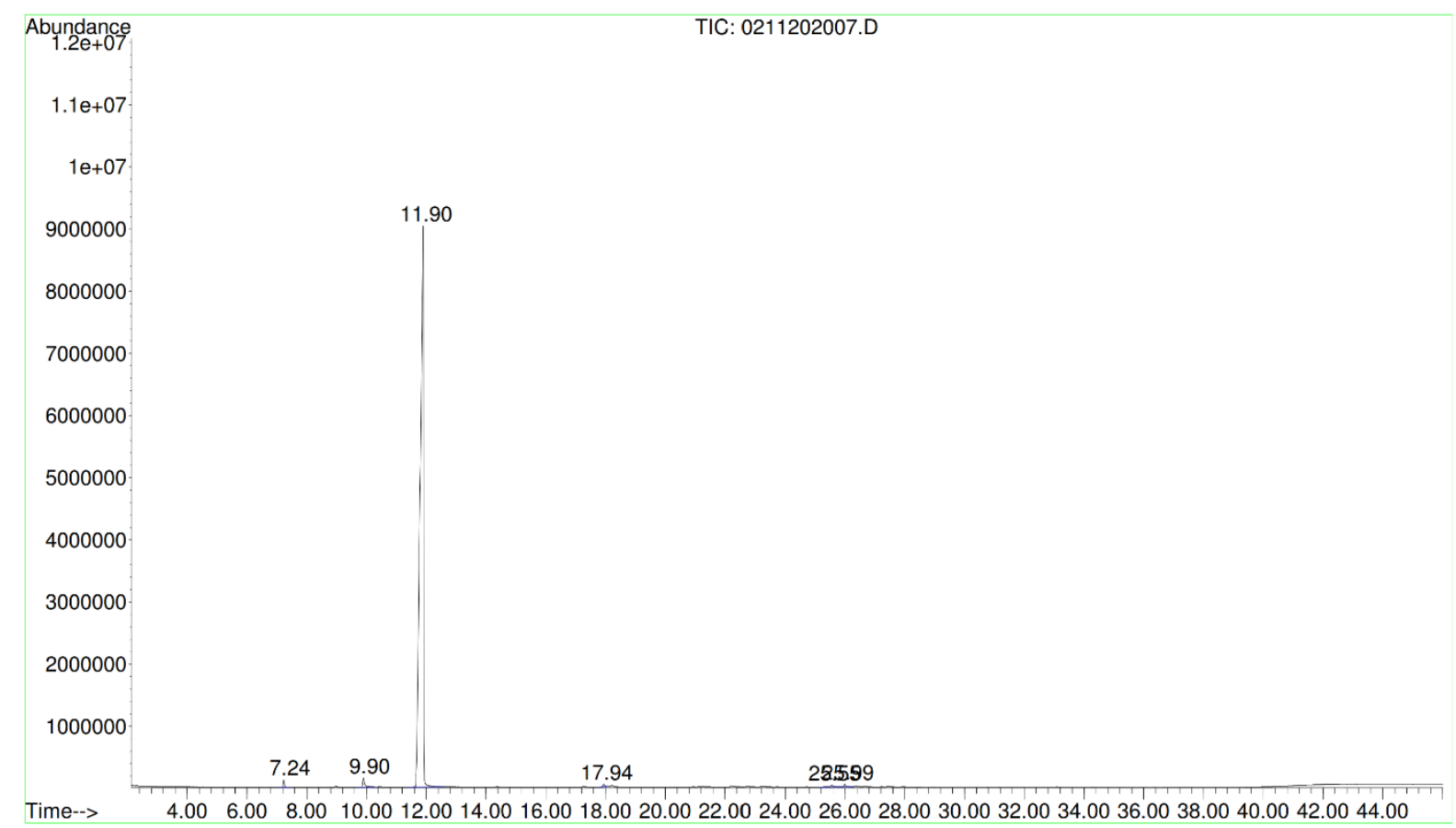

FIGURE 6. GC-MS chromatogram of the pomelo peels oil by hydro-distillation

\section{CONCLUSION}

In this study, kinetics of the hydro-distillation process that utilized pomelo peels to produce essential oils was modeled at different distillation rate. The results show that most of the adopted experimental models have been proven to be suitable for the model of pomelo oil kinetics in operating conditions $\left(\mathrm{R}^{2}>0.90\right)$. The simultaneous washing and diffusion model is best suited to represent the kinetics of the pomelo peel oil hydro-distillation. This model (with the highest $\mathrm{R}^{2}$ value of 0.9997 ) fits the experimental data better than the other two kinetic models. Estimated parameters have also shown that the washing stage occurs more rapidly than the later, diffusion stage of hydro-distillation. In addition, GC-MS results show that the obtained essential oil is predominated with Limonene, having the content at around $97.873 \%$.

\section{ACKNOWLEDGEMENTS}

This research is funded by the Science and Technology Program of Ministry of Education and Training (Vietnam) with Sub-Project code: CT2020.01.TCT-07. 


\section{REFERENCES}

Burcu Uysal, Fazli Sozmen, Ozgur Aktas, Birsen S. Oksal \& Elif Odabas Kose. 2011. Essential oil composition and antibacterial activity of the grapefruit (Citrus paradisi L.) peel essential oils obtained by solvent-free microwave extraction: Comparison with hydrodistillation. International Journal of Food Science \& Technology 46(7): 1455-1461. https://doi. org/10.1111/j.1365-2621.2011.02640.x.

Charchari, S. \& Hamadi, S. 2007. Kinetic study of Artemisia judaica L. essential oil steam distillation. Journal of Essential Oil Bearing Plants 10(4): 304-309. https://doi.org/10.1080/ 0972060X.2007.10643559.

Chen, H-C., Peng, L-W., Sheu, M-J., Lin, L-Y., Chiang, H-M., Wu, C-T., Wu, C-S. \& Chen, Y-C. 2013. Effects of hot water treatment on the essential oils of calamondin. Journal of Food and Drug Analysis 21(4): 363-368. https://doi.org/10.1016/j. jfda.2013.08.003.

Desai, M.A., Parikh, J. \& De, A.K. 2014. Modelling and optimization studies on extraction of lemongrass oil from Cymbopogon flexuosus (Steud.) wats. Chemical Engineering Research and Design 92(5): 793-803. https:// doi.org/10.1016/j.cherd.2013.08.011.

Dhobi, M., Mandal, V. \& Hemalatha, S. 2009. Optimization of microwave assisted extraction of bioactive flavonolignansilybinin. J. Chem. Metrol. 3: 13-23.

Díaz Reinoso, Beatriz, María Jesús González Muñoz, and Herminia Domínguez González. 2017. Introduction. In Water Extraction of Bioactive Compounds. Elsevier. pp. 1-50. https://doi.org/10.1016/B978-0-12-809380-1.00001-2.

General Statistics Office of Vietnam. Thông cáo báo chí về tình hình kinh tế - xã hội quý III và 9 tháng năm 2019. https:// gso.gov.vn/default.aspx?tabid=382\&idmid=2\&Item $\mathrm{ID}=19362$.

González-Mas, M.C., Rambla, J.L., López-Gresa, M.P., Blázquez, M.A. \& Granell, A. 2019. Volatile compounds in citrus essential oils: A comprehensive review. Frontiers in Plant Science 10: 12. https://doi.org/10.3389/fpls.2019.00012.

Haqqyana, H., Tania, V.F.W., Suyadi, A.M., Kusuma, H.S., Altway, A. \& Mahfud, M. 2020. Kinetic study in the extraction of essential oil from clove (Syzgium aromaticum) stem using microwave hydrodistillation. Mor. J. Chem. 8: 64-71.

Jutarut Pornpunyapat, Pakamas Chetpattananondh \& Chakrit Tongurai. 2011. Mathematical modeling for extraction of essential oil from Aquilaria crassna by hydrodistillation and quality of agarwood oil. Bangladesh Journal of Pharmacology 6(1): 18-24. https://doi.org/10.3329/bjp. v6il.7902.

Karim Hosni, Nesrine Zahed, Raouf Chrif, Ines Abid, Wafa Medfei, Monem Kallel, Nadia Ben Brahim \& Houcine Sebei. 2010. Composition of peel essential oils from four selected Tunisian Citrus species: Evidence for the genotypic influence. Food Chemistry 123(4): 1098-1104. https://doi.org/10.1016/j. foodchem.2010.05.068.

Kitanović, S., Milenović, D. \& Veljković, V.B. 2008. Empirical kinetic models for the resinoid extraction from aerial parts of St. John's wort (Hypericum perforatum L.). Biochemical Engineering Journal 41(1): 1-11. https://doi.org/10.1016/j. bej.2008.02.010.

Krishnan, R.Y. \& Rajan, K.S. 2017. Influence of microwave irradiation on kinetics and thermodynamics of extraction of flavonoids from Phyllanthus emblica. Brazilian Journal of Chemical Engineering 34(3): 885-899. https://doi. org/10.1590/0104-6632.20170343s20150628.

Kusuma, H.S. \& Mahfud, M. 2017. Comparison of kinetic models of oil extraction from sandalwood by microwave-assisted hydrodistillation. Int. Food Res. J. 24: 1697-1702.

Lan-Phi, N.T. \& Vy, T.T. 2015. Chemical composition, antioxidant and antibacterial activities of peels' essential oils of different pomelo varieties in the south of Vietnam. Int. Food Res. J. 22(6): 2426-2431.

Mardawani Mohamad, Mohamad Wijayanuddin Ali, Adnan Ripin \& Arshad Ahmad. 2012. Effect of extraction process parameters on the yield of bioactive compounds from the roots of Eurycoma longifolia. Jurnal Teknologi 60: 51-57. https://doi.org/10.11113/jt.v60.1441.

Marković, M.S., Milojević, S.Ž., Bošković-Vragolović, N.M., Pavićević, V.P., Babincev, L.M. \& Veljković, V.B. 2019. A new kinetic model for the common juniper essenstial oil extraction by microwave hydrodistillation. Chinese Journal of Chemical Engineering 27(3): 605-612. https:// doi.org/10.1016/j.cjche.2018.06.022.

Mateus, E.M., Carlos, L., Nogueira, T., Lourenço, J.A.A. \& Marcelo Curto. M.J. 2006. Pilot steam distillation of Rosemary (Rosmarinus officinalis L.) from Portugal. Silva Lusitana 14(2): 203-217.

Milojević, S.Ž., Stojanović, T.D., Palić, R., Lazić, M.L. \& Veljković, V.B. 2008. Kinetics of distillation of essential oil from comminuted ripe juniper (Juniperus communis L.) berries. Biochemical Engineering Journal 39(3): 547-553. https://doi.org/10.1016/j.bej.2007.10.017.

Milojevic, S.Z., Radosavljevic, D.B., Pavicevic, V.P., Pejanovic, S. \& Veljkovic, V.B. 2013. Modeling the kinetics of essential oil hydrodistillation from plant materials. Hemijska Industrija 67(5): 843-859. https://doi.org/10.2298/ HEMIND121026009M.

Minh Tu, N.T., Thanh, L.X., Une, A., Ukeda, H. \& Sawamura, M. 2002. Volatile constituents of Vietnamese pummelo, orange, tangerine and lime peel oils. Flavour and Fragrance Journal 17(3): 169-174. https://doi.org/10.1002/ffj.1076.

Morton, J.F. \& Dowling, C.F. 1987. Fruits of Warm Climates. Miami, FL: J.F. Morton.

Nguyen Dang Binh Thanh, Nguyen Trung Dung \& Ta Hong Duc. 2018. Modeling of essential oil extraction process: Application for orange, pomelo, and lemongrass. Vietnam Journal of Science and Technology 56(4A): 182. https://doi. org/10.15625/2525-2518/56/4A/12811.

Puglisi, I., De Patrizio, A., Schena, L., Jung, T., Evoli, M., Pane, A., Nguyen Van Hoa, Mai Van Tri, Wright, S., Ramstedt, M., Olsson, C., Faedda, R., di San Lio, G.M. \& Cacciola, S.O. 2017. Two previously unknown Phytophthora species associated with brown rot of pomelo (Citrus grandis) 
fruits in Vietnam. PLoS ONE 12(2): e0172085. https://doi. org/10.1371/journal.pone.0172085.

Quyen, Ngo, Tran Thi Kim Ngan, Tan Phat Dao, Phan Nguyen Quynh Anh, Ngo Quoc Anh, Ngoc-Tram Nguyen Thi, Thuy Trang Le Ngoc, Le Thi Hong Nhan, Tran Thanh Truc, \& Le Thi Bich Phuong. 2019. Essential oil hydrodistillation process from Vietnamese calamondin (Citrus microcarpa) peels and GC/MS analysis of essential oils components. Asian Journal of Chemistry 31(11): 2585-2588. https://doi.org/10.14233/ ajchem.2019.22148

Sovová, H. \& Aleksovski, S.A. 2006. Mathematical model for hydrodistillation of essential oils. Flavour and Fragrance Journal 21(6): 881-889. https://doi.org/10.1002/ffj.1729.

Sowbhagya, H.B., Sathyendra Rao, B.V. \& Krishnamurthy, N. 2008. Evaluation of size reduction and expansion on yield and quality of cumin (Cuminum cyminum) seed oil. Journal of Food Engineering 84(4): 595-600. https://doi.org/10.1016/j. jfoodeng.2007.07.001.

Stanisavljević, I.T., Lazić, M.L., Veljković, V.B., Stojičević, S.S., Veličković, D.T. \& Ristić, M.S. 2010. Kinetics of hydrodistillation and chemical composition of essential oil from cherry laurel (Prunus laurocerasus L. var. Serbica Pančić) leaves. Journal of Essential Oil Research 22(6): 564-67. https://doi.org/10.1080/10412905.2010.9700401.

Tan Phat Dao, Ngo Thi Cam Quyen, Thien Hien Tran, Pham Van Thinh, Pham Quoc Long, Tran Quoc Toan, Ngoc Hoi Nguyen, Do Minh Hoang Vo, Xuan Tien Le, Le Nguyen Yen Trung, Thi Thuong Nguyen, Tran Thi Yen Nhi, Tran Thanh Truc \& Nguyen Van Muoi. 2020. Optimization of operating conditions of essential oil extraction of Vietnamese pomelo (Citrus grandis L.) peels by hydrodistillation process. Asian Journal of Chemistry 32(2): 237-243. https://doi. org/10.14233/ajchem.2020.22179.

Tan Phat Dao, Thien Hien Tran, Thi Cam Quyen Ngo, Huynh Thi Kieu Linh, Le Nguyen Yen Trung, Vo Thanh Danh, Thuy Trang Le Ngoc, Nguyen Dong Yen Pham, Pham Minh Quan \& Tran Quoc Toan. 2019. Extraction of essential oils from Vietnam's orange (Citrus sinensis) peels by hydrodistillation: Modeling and process optimization. Asian Journal of Chemistry 31(12): 2827-2833. https://doi.org/10.14233/ ajchem.2019.22178

Thien Hien Tran, Tri Duc Lam, Van Tien Nguyen, Tan Phat Dao, Le Thi Hong Nhan, Tran Quoc Toan, Dai-Viet N. Vo, Tran Anh Vy \& Le Minh Bui. 2019a. Response surface methodology for optimization studies of microwaveassisted hydrodistillation of essential oil from Vietnamese Citrus aurantifolia (lemon fruit). IOP Conference Series: Materials Science and Engineering 542: 012042. https://doi. org/10.1088/1757-899X/542/1/012042.

Thien Hien Tran, Le Ke Ha, Duy Chinh Nguyen, Tan Phat Dao, Le Thi Hong Nhan, Dai Hai Nguyen, Trinh Duy Nguyen, Dai-Viet N. Vo, Quoc Toan Tran \& Long Giang Bach. 2019b. The study on extraction process and analysis of components in essential oils of black pepper (Piper nigrum L.) seeds harvested in Gia Lai Province, Vietnam. Processes 7(2): 56. https://doi.org/10.3390/pr7020056.

Viet Van Hoang. 2014. Value chain analysis and competitiveness assessment of Da Xanh pomelo sector in Ben Tre, Vietnam. Asian Social Science 11(2): 8. https://doi.org/10.5539/ass. v11n2p8.

\section{Tan Phat Dao}

Graduate University of Science and Technology

Vietnam Academy of Science and Technology, Hanoi Vietnam

Tan Phat Dao \& Long Giang Bach*

Center of Excellence for Biochemistry and Natural Products

Nguyen Tat Thanh University

Ho Chi Minh City

Vietnam

Tan Phat Dao \& Long Giang Bach*

Institute of Environmental Technology and Sustainable Development

Nguyen Tat Thanh University

Ho Chi Minh City

Vietnam

Huynh Xuan Phong

Biotechnology Research and Development Institute

Can Tho University

Can Tho City

Vietnam

Mai Huynh Cang

Department of Chemical Engineering and Processing

Nong Lam University

Ho Chi Minh City

Vietnam

Nguyen Van Muoi

College of Agriculture

Can Tho University

Can Tho City

Vietnam

*Corresponding author; email: blgiang@ntt.edu.vn

Received: 12 June 2020

Accepted: 3 March 2021 